Community: volume 6, nomor 1, April 2020

p-ISSN: 2477-5746 e-ISSN: 2502-0544

\title{
PRELIMINARY RESEARCH ON THE SURVIVAL STRATEGIES AMONG PALA'O PEOPLE IN BANGGI ISLAND
}

\author{
Dzurizah Ibrahim ${ }^{1}$, Jalihah Md Shah ${ }^{2}$ \\ Universiti Malaysia Sabah \\ idzuri@ums.edu.my ${ }^{1}$, jalihah@ums.edu.my²
}

\begin{abstract}
Abstrak
Makalah ini merupakan penelitian awal ke atas kelangsungan hidup etnik Pala'o yang tinggal di Pulau Banggi yang terletak di utara negeri Sabah, Malaysia. Pulau Banggi diduduki oleh pelbagai etnik dan suku etnik Bajau Ubian, Dusun Bonggi, Suluk, Kegayan, Bajau Sama' dan Molbog mendominasinya. Kini, Pulau Banggi turut didiami oleh suku etnik Pala'o yang juga dikenali sebagai Bajau Laut, Sama Dilaut, dan Palauh yang berasal dari kawasan perairan Semporna di Laut Sulu dan Celebes. Berdasarkan pendekatan kualitatif menerusi temu bual mendalam, suku Pala'o yang ada di pesisir jeti Pekan Karakit, Pulau Banggi didapati berupaya untuk mengadaptasi perubahan yang berlaku dalam persekitaran dan mengubahnya mengikut kesesuaian mereka. Keperluan untuk meneruskan kehidupan dilihat sebagai asas penting 'penghijrahan' etnik ini. Kajian mendapati bahawa untuk kelangsungan hidup, suku Pala'o dalam konteks kajian ini mengadaptasi empat strategi kelangsungan hidup iaitu migrasi laut ke darat, strategi fizikal, strategi sosial dan strategi ekonomi. Meskipun begitu, nasib etnik Pala'o ini kekal sebahagian besarnya tidak berubah. Mereka masih dibelenggu kemiskinan dan mereka selalu, dan masih lagi kekal menjadi etnik 'tanpa kewarganegaraan'. Adapun kejayaan sesuatu strategi kelangsungan hidup dilihat amat berkait rapat dengan sektor ekonomi dan pekerjaan yang dilakukan, pengetahuan, kemahiran serta pendidikan namun ia tidak berlaku pada suku Pala'o ini. Kehidupan mereka masih dilihat berdepan kesukaran dek kemiskinan namun desakan hidup telah membuatkan mereka cekal meneruskan kehidupan biarpun kehidupan di daratan berbeza dari kisah hidup mereka di laut luas.
\end{abstract}

\section{Kata Kunci: Etnik Pala'o/Palauh/Bajau Laut; Strategi kelangsungan hidup; kemiskinan; pekerjaan informal}




\section{Introduction}

This paper is based on a preliminary study of the survival of Pala'o ethnic group living in Banggi Island located in the northern part of Sabah, Malaysia. According to local legend, the name of Banggi Island comes from the name of the Bajau tribe that dominated the former Banggi-Palawan-Sulu archipelago. The Bajau tribe named Banggi Island as Ba ngie meaning Bangie people. Banggi Subdistrict was reported on January 1, 1975 as Banggi Subdistrict, which is approximately $36.1 \mathrm{~km}$ from the mainland of Kudat. Banggi Island is located north of the state map of Sabah measuring 270 square miles, with a population of about 13,731 people. Apart from the mainland of Banggi, there are also five large islands and 31 smaller islands around it. When travelling by ferry, the distance from Banggi-Kudat Island takes 1 hour and 30 minutes.

Banggi Island is inhabited by various ethnic groups and ethnic groups of Bajau Ubian, Dusun Bonggi, Suluk, Kagayan, Bajau and Molbog. However, Banggi Island is now inhabited by the Pala'o ethnic group, also known as the Sea Gypsies, Bajau Dilaut and Palauh. The presence of these Pala'o people has greatly diverse the lives of the locals.

The Pala'o people are great seafarers, who have been exploring the waters of the Coral Triangle between Malaysia, the Philippines and Indonesia for generations. Today, the Pala'o people are seen occupying the seafront and also treading the land by living in wooden boats or erecting small cottages built on coral reefs near the mainland. Most of these Pala'o people are located in the coastal waters of Sulu and Celebes in Semporna on the east coast of Sabah bordering the Philippines and Indonesia.

In Banggi Island, the traditional habit of Pala'o ethnic life swirling with the vast open ocean is now beginning to appear near the Karakit Town jetty at Banggi Island. Although they still lived in the wooden boat, they began interacting with outside communities besides their own. This is seen in contrast to the strong Pala'o community around the islands of Semporna. The need to continue living is seen as an essential part of this 'migrant' ethnicity.

However, Pala'o's ethnic fate remains largely unchanged. They are still subjected to poverty and they have always been and remain ethnic 'without citizenship'. According to the United Nations (UNHCR, 2016), there are more than 10 million people without citizenship in the world. In Peninsular Malaysia, there are at least 10,000 people denied citizenship, and there is no clear figure on the number of non-citizens in Sabah and Sarawak (UNHCR, 2019). According to the United Nations Convention Relating to the Status of Citizenship (2019), stateless persons are "persons not considered citizens by any 
Community: volume 6, nomor 1, April 2020

p-ISSN: 2477-5746 e-ISSN: 2502-0544

country under the enforcement of their laws,". In other words, the person is not protected by any country and does not have the basic rights of a citizen.

In Sabah, most Pala'o people are ethnic without citizenship nor are they belong to either Malaysia, the Philippines or Indonesia, as they are considered to be residents of the waters of the Sulu Sea and Celebes, and are not owned by any country. As a result, most of their children do not have access to the formal education system, due to the lack of documents such as birth certificates and even their identity cards.

This continues to be their identity even as they begin to occupy the shores and piers of Karakit Town. Without a job that guarantees their lives, the 'migration' from the sea to the mainland raises questions about their survival. Therefore, this paper will discuss Pala'o ethnic survival strategies in Banggi Island.

\section{Literature Review}

In Malaysia, various research have been conducted pertaining to the involvement of foreign workers particularly in Sabah, as economic contributors in the agriculture, construction, fisheries or other informal sectors (Ho Ting Seng, 1989; Zulkifly, 1989; Azizah, 2004; Ismail, 2008; Dayang Suria, 2009; Dzurizah \& Jalihah, 2014). In addition, studies on the acculturation and survival strategies among immigrants in Sabah also take place (Halina, 2003; Dzurizah et al., 2019).

A study on the acculturation experience and process of cultural adaptation among Filipino immigrants in Sabah by Halina (2003) highlights four critical elements: (1) the group is observed to be inclined towards integrating local cultures and norms while being steadfast in their own traditions, (2) linguistic ability or competency has a critical role in ensuring the acculturation behaviour, (3) knowledge of culture, perception towards that culture and personal relationships generated with the local community assist in the acculturation process, and (4) all these aspects are interrelated in determining the ease of acculturation among immigrants. The findings of this study point to acculturation into the local culture as key in the survival strategies of Filipino immigrants in Sabah with the element of communication singled out as a key aspect for successful integration. This situation could be better elaborated by examining other elements that might influence or determine the survival strategies of immigrants in their host countries.

In addition to Filipino immigrants, Sabah is also a popular destination for Indonesian workers. A total of 260, 000 Indonesian immigrant labour was documented by the Indonesian Consulate in Sabah in 2015 (Ramli \& Mohd. Kamarulnizam, 2015) in comparison to the 313,652 that officially registered with the Indonesian Consulate in June 2011 (Konsulat Indonesia Sabah, 2011). 
The study of Dzurizah et al. (2019) on survival strategies among Indonesian immigrants in the city of Kota Kinabalu found seven practices of survival strategies. To ensure the survival of immigrants from their home countries, the study of Dzurizah et al. (2019) found that Javanese entrepreneurs in Kota Kinabalu ensure that they adopt seven elements of capital accumulation; employment relations; skills; collective and positive values; network; citizenship status as well as; acceptance, commitment and desire. However, this strategy is used by Javanese immigrants who are concentrated in the food business world and do not cover other immigrants who may be living in different sectors or industries. If this survival strategy successfully strengthened the socio-economic status of Javanese entrepreneurs in Kota Kinabalu, what is the survival strategy for Pala'o people in Banggi Island? Are they adapting or practicing any survival strategy to sustain their lives especially when they migrating from sea to mainland? As study on the survival strategy of Pala'o ethnic, who also known as people without citizen, is still under-researched, this is the aim of this paper to identify survival strategies of Pala'o people living in Banggi Island. Such is the premise of this paper.

\section{Methodology}

Based on qualitative methods, in-depth interviews and observations were conducted on three Pala'o ethnic families living in a wooden boat by the Karakit Town Pier in Banggi Island. The interviews lasted between 60 minutes and 90 minutes at a time. Most interviews take place when informants are on land, but there are instances where interviews are conducted in wooden boats where informants live in order to get a true picture of their life experiences.

The ethnic life of this Pala'o is primarily in wooden boats and in the sea. Most of the time, they will be in the ocean and only in certain seasons will they be on land and in the mainland. It is also known as Palauh, Bajau Laut, Sama Dilaut or sea gypsy because this ethnic lifestyle is nomadic and popularly known as seafarer. Most of these ethnic groups come from the waters of Semporna, on the east coast of Sabah and this includes the respondents in the study. The study was confined to three families who had migrated and lived in three boats off the coast of Karakit Town in Banggi Island alone.

\section{Findings and Discussion}

Although these three Pala'o families have lived on the outskirts of Karakit town, the traditional life on the wooden boat continues. One of these ethnic family couples lives in a 9 X 3 feet wooden boat with eight children of unknown age except for a newborn baby a few months ago. So are two other families. Living in a wooden boat is not an option as it is 
Community: volume 6, nomor 1, April 2020

p-ISSN: 2477-5746 e-ISSN: 2502-0544

their tradition of living on the vast seas and when they arrive inland, the same 'home' is still inhabited. If not, the Karakit weekend jetty will be occupied at nightfall or the beach below the free beam of street lights will be an option.

This preliminary study found that despite the challenges of living off the coast of Pekan Karakit in Banggi Island, the Pala'o ethnic group was found to be striving for survival. The study found that there are several survival strategies that justify the ethnic Pala'o to continue to adapt to the local community in Karakit town. In contrast to the seven survival strategies of Indonesian immigrants in a food company in the city of Kota Kinabalu, Sabah (Dzurizah et al., 2019), the Pala'o ethnic groups in this initial study were unable to separate themselves from the shackles of poverty. The study of Dzurizah et al. (2019) on the survival strategies of Indonesian immigrants in the city of Kota Kinabalu have found that they can transform the status quo and their economy to positively impact the spillover effect and help the local community. In contrast, a study of the Pala'o community on Banggi Island found different findings.

To ensure the survival of their life, the Pala'o ethnic family leader is involved in economics and informal employment. If at sea, they become seafarers living on the source of the oceans, on the mainland they seek rice through the labor of earning salaries by raising the revenues of the sea and unloading locals seafood to ferries. This shows how the survival strategies adopted by informants are short-term and temporary. In fact, according to Beck's (1989) study, Pala'o's ethnic strategy was seen as more 'desperate' to ensure the survival of informant families. There are no definite terms of 'employment relationship' because the nature of the job involved is temporary, unsecured and the employer-employee relationship is not clearly represented. This indirectly indicates that the job involved is precarious (Dzurizah \& Nurizan, 2018).

Being on land also led to a barter-based (barter) economic system that had to be transformed into a trading system involving money transactions. Therefore, whether they want to or not, they have no choice but to work by exchanging their sweat with money to get what they need.

Life is exposed to foreign communities that exist in the town Karakit has also opened a space for ethnic Pala'o to speak in Malay language with Sabah dialect. This is so because by mastering Malay language with Sabah dialect only possible for them to communicate with local residents to facilitate their work and dealing daily affairs. This indicates that the migration of the Pala'o community from Semporna to Banggi Island has contributed to the exploration of languages other than their own. This is in part supported by the study of Halina (2003) who found how Filipinos in Sabah adapted and culturally adapted to the culture and language of the local people for their survival. 
Exposure to the land and locals has also made it possible for Pala'o teenagers to learn about music and entertainment, beauty and fashion for example, even though life is still in poverty and is still backward compared to other communities in the area. What is clear is that enjoying the music as entertainment and being beautiful is not a sin as the Pala'o children are beginning to realize the pleasures of the world they never experienced while in the great sea. Thus, it can be seen that social adaptation also plays a role in ensuring that Pala'o ethnic life can be lived as it should.

In terms of basic facilities and utilities, schools are not an option but basic amenities such as health clinics are available at the expense of foreigners in case of emergency. For water supply, the police station is only 200 meters away and the mosque 100 meters away will be the place to get drinking water if needed. Despite the free water supply but without the basic utilities, the informants did not feel it was an impediment to their survival on the mainland.

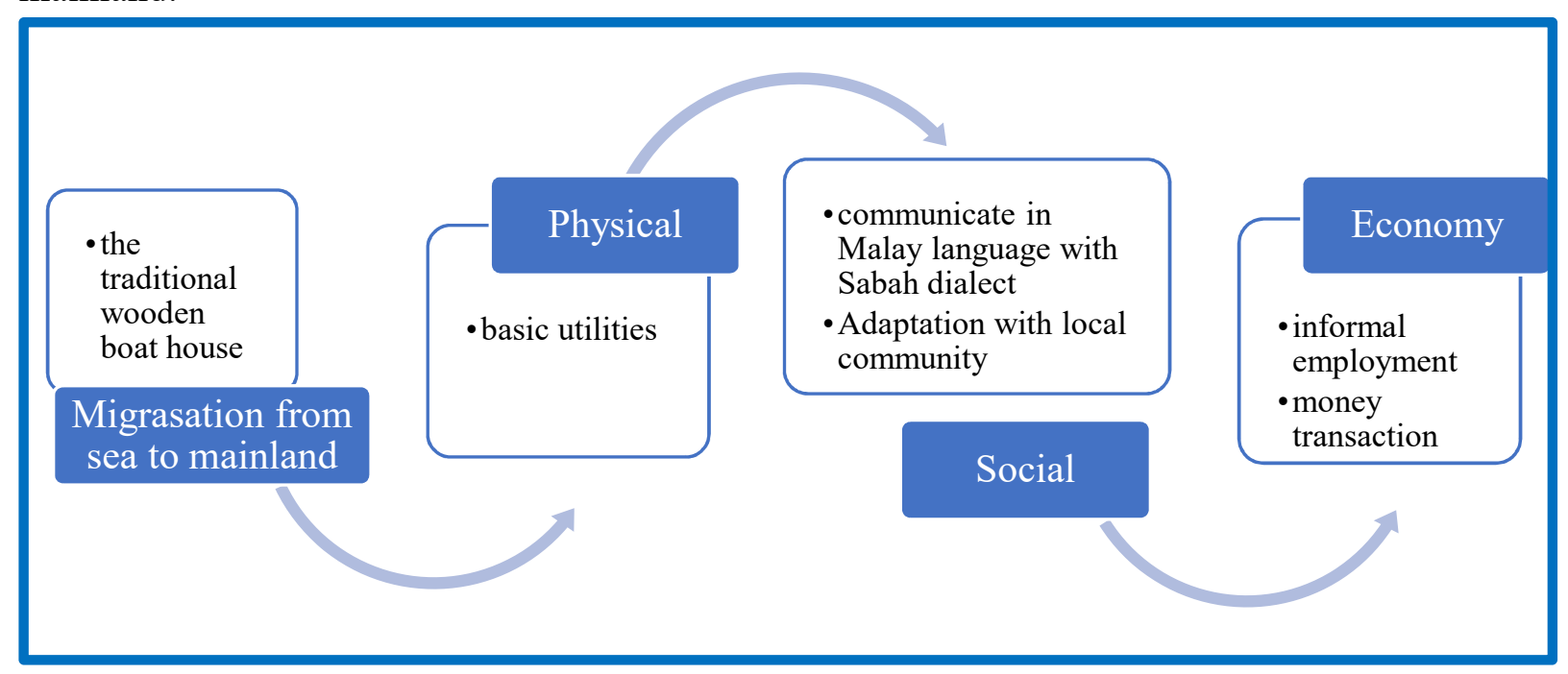

Figure 1: Pala'o Ethnic Survival Strategy in Banggi Island

Figure 1 illustrates the findings of the Pala'o ethnic survival strategy in Banggi Island. This finding is in stark contrast to other studies such as Indonesian immigrants in the city of Kota Kinabalu (Dzurizah et al., 2019) that show their success as immigrants (see Figure 2). 
Community: volume 6, nomor 1, April 2020

p-ISSN: 2477-5746 e-ISSN: 2502-0544

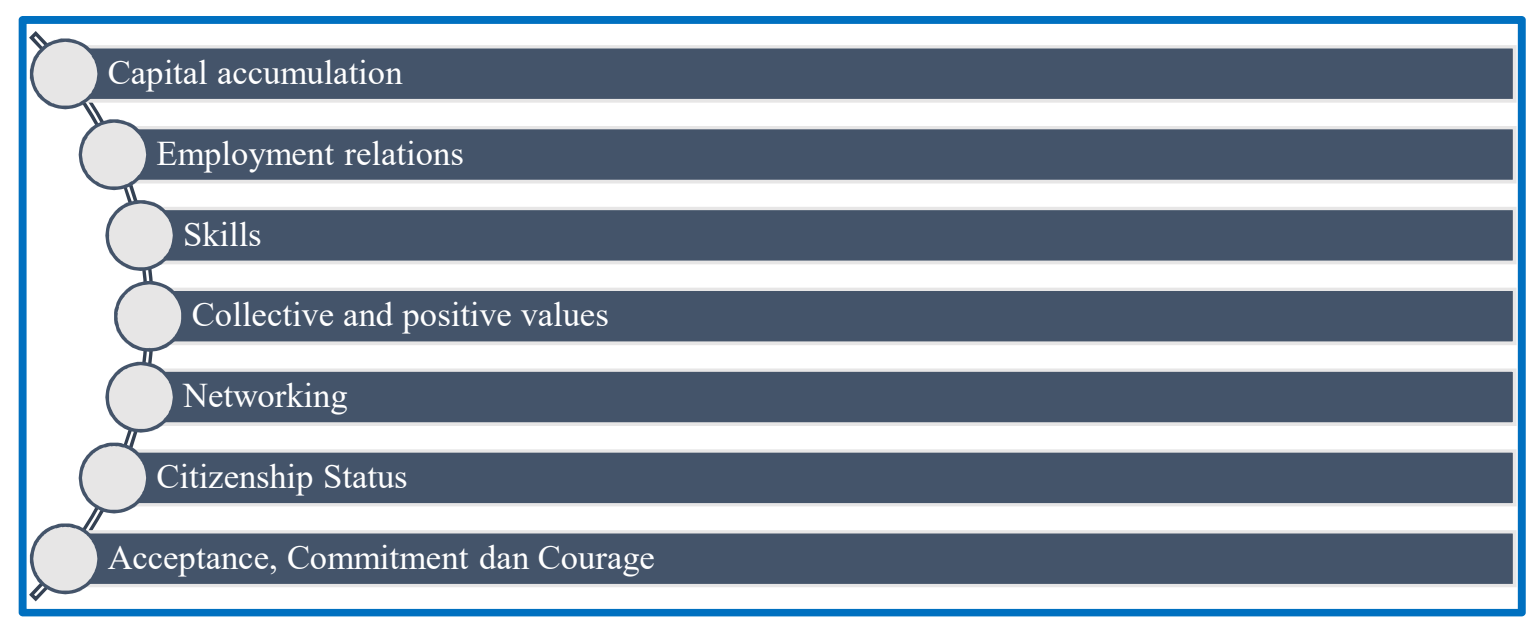

Sumber: Dzurizah Ibrahim et al. (2019)

Figure 2: Seven Survival Strategies of Indonesian Immigrants in Kota Kinabalu, Sabah.

In this study, the Pala'o community has managed to survive but the poverty cycle has not changed. The success of a survival strategy is seen to be closely linked to the economic sector and the work it does, knowledge, skills and education. What is more important is that they can be achieved more easily with citizenship status.

\section{Conclusion}

The Pala'o community on the shores of Pekan Karakit, Banggi Island was found to be able to adapt to changes in the environment and adapt to their needs. Although their lives are still facing hardships on the poverty, their insistence has led them to continue living even though life on the land is different from their life story in the open sea. Adapting to interact with locals who are not of the same ethnicity has made these Pala'o ethnic groups open themselves to the language and way of life of other communities. If people in big cities have been talking about the industrial revolution 4.0 or about how fast broadband is when using internet devices, or at least about digital television exchanges that end in stages across the country, Pala'o's children hear a row of Hindustani songs just enough to make their hearts blossom and their lips smile. Which of God's favors would you rather deny? 
p-ISSN: 2477-5746 e-ISSN: 2502-0544

\section{References}

Azizah Kassim (2004). 'Illegal immigrants and the state in Sabah: Conflicting interests and the contest of will.' Kertas kerja dibentangkan di Closed Workshop on State Responses to the Presence and Employment of Foreign Workers in Sabah. Anjuran Unit Penyelidikan Pembangunan dan Etnografi, Sekolah Sains Sosial, Universiti Malaysia Sabah. 25 Februari.

Beck, T. (1989). 'Survival Strategies and Power amongst the Poorest in a West Bengal Village'. IDS Bulletin. 20 (2). 23-32.

Dayang Suria Mulia (2019). 'Pekerja Asing di Sabah: Isu dan Perspektif.' Dalam Dzurizah Ibrahim et al. (pytg.). Hubungan Industri dan Sumber Manusia. Isu dan Perspektif. (Edisi Ketiga). Kota Kinabalu: Universiti Malaysia.

Dzurizah Ibrahim \& Jalihah Md Shah (2014). Buruh Kanak-kanak di Sabah. Kota Kinabalu: Universiti Malaysia Sabah.

Dzurizah Ibrahim, Jalihah Md. Shah \& Rose Patsy Tibok. (2019).'Survival strategies among Indonesian Immigrants in Kota Kinabalu, Sabah, Malaysia. Jurnal Populasi. 27 (1). 34-45.

Dzurizah Ibrahim \& Nurizan Johar. (2018). Contract Workers in Public Sector: Precarious or Opportunity? Proceeding ILERA World Congress. South Korea: ILERA.

Halina Sendera Mohd. Yakin. (2003). Akulturasi Imigran Filipina. Generasi Pertama dan Kedua di Sabah. Kota Kinabalu: Universiti Malaysia Sabah.

Haralambos M. (1980). Sociology: Themes and Perspective. London: Open University Press.

Ho Ting Seng (1989). 'International immigration in urban development: The case of the Filipino immigrants in Sabah'. Dalam Mohd Yaakub Hj. Johari \& Baldev S. Sidhu. (eds.). Urbanisation and Development: Prospects and Policies for Sabah Beyond 1990. Kota Kinabalu: Institute for Development Studies.

Ismail Ali. (2008). 'Penglibatan dan sumbangan kanak-kanak warga Filipina dalam ekonomi perikanan di Sabah: Satu Pengadilan Moral?' Sosio Humanika. Vol. 1. No. 3. November. 
Community: volume 6, nomor 1, April 2020

p-ISSN: 2477-5746 e-ISSN: 2502-0544

Ramli Dollah \& Mohd. Kamarulnizam Abdullah. (2015). 'Pembangunan Ekonomi dan Krisis Tenaga kerja Aing di Sabah'. Kertas kerja dibentangkan dalam Persidangan Malaysia-Indonesia ke-9. Jogjakarta, Indonesia.

UNHCR. (2019). 'Ending Statelessness in Malaysia'. https://www.unhcr.org/enmy/ending-statelessness-in-malaysia.html (akses pada 14 Oktober 2019).

UNHCR. (2016). UNHCR Statistical Yearbook 2016. Switzerland: UNHCR

Zulkifly Hj. Mustapha (1989). 'The role of the informal sector in urban development'. Dalam Mohd Yaakub Hj. Johari \& Baldev S. Sidhu. (eds.). Urbanisation and Development.: Prospects and Policies for Sabah Beyond 1990. Kota Kinabalu: Institute for Development Studies. 